\title{
坚持立德树人 提升语文教学实效
}

\author{
王高梅 \\ 山东省临沭县第五实验小学 \\ DOI:10.32629/jief.v2i10.2325
}

[摘 要] 小学生处于心智、世界观等方面都尚未成熟的阶段, 而小学阶段恰恰又是学生德智体美劳等各个方面能够得到有效锻炼的黄金时期。 因此, 在小学阶段中搞好学生的身心健康教育至关重要。小学教育不能仅仅依赖相对生硬的书本知识, 还要注意课外知识的拓展, 尤其注重 学生思想品德的培养教育, 帮助学生形成健康正确的价值观。在小学教育中融入 “立德树人”教育品质, 有利于中华民族优秀文化传统的继 承与弘扬，也符合现代素质教育的要求。本文将探讨立德树人融入小学语文教育中的策略。

[关键词] 小学语文教育; 立德树人教育; 融入途径

中图分类号: G623 文献标识码: A

\section{引言}

语文学科兼具人文性和工具性。语文在帮助学生学会交际技巧, 提 升表达能力的同时, 也能够促进提升学生的人文素养。在传递知识的过 程中提升学生的思想品德修养。在改革之后的《语文课程标准》等相关 文件中, 明确地指出要重视语文课程的人文性一面。不能因为学科知识 的学习、考试成绩的提升而忽视了对学生进行品德素质教育的过程。在 语文教育的过程中要兼顾对两方面教育内容的重视, 提升学生的综合素 养。

\section{1 立德树人背景下小学语文德育渗透的重要意义}

1.1 有利于促进学生道德品格的教育培养

小学教育阶段正是学生道德观念形成的重要时期, 这个时期学生接 受的各种知识思想有很大可能对学生产生重要影响, 尤其是小学生自身 的智力水平还有待提高, 对外界事物缺乏明确的辨别能力, 容易受到不 良思想的影响, 危害学生今后的生活和学习。因此需要加强对学生的道 德品格, 而语文课程中有着大量关于道德品格的文章, 通过有效的教学 引导, 可以促使学生受到德育熏陶, 让学生在学习过程中逐渐受到影响, 从而实现对学生良好品格的培养。

1.2 有助于丰富语文课堂的教学内容

在小学语文教学中开展德育的渗透, 不仅适应了立德树人的教学目 标, 也是教师开展对学生教育的重要途径, 教师可以通过对道德品格的 教育渗透, 将语文课程中关于道德观念的知识进行详细的分析教授, 利 用各种优秀文章对学生进行各种知识点的教育, 可以极大的丰富课堂的 教学内容, 形成丰富多彩的语文课堂模式, 促进小学语文课程的高效教 学。

\section{2 立德树人背景下小学语文德育渗透的策略探究}

2.1 更新传统的教学模式, 明确立德树人的教学目标

在立德树人背景下小学语文教学中进行德育渗透, 是适应新课程改 革发展的客观需要, 教师在小学教育中不仅需要教授学生各种语文知识 点, 让学生通过专业技能, 还需要不断的提高学生的道德素质, 促进学 生的综合素质培养, 因此教师需要加强对德育教学的重视, 结合学生的 实际情况, 更新传统的语文教学模式, 明确立德树人的教学目标, 促进 学生良好道德品格的培养。

2.2 结合语文的课程教材, 引导学生的情感教学体验

在现代的语文教材中有着各种形式和思想的文章, 其中包含着各种 高尚的道德思想, 包括爱护动物、团结互助、热爱祖国、遵纪守法等,
可以有效的進行对学生的教育培养, 因此在小学语文课程中教师要开展 对学生的德育教学, 就需要加强对语文课程的分析, 结合教材中的各种 文章内容, 对学生进行针对性的教育引导, 让学生在学习过程中得到有 效的情感体验, 促进学生正确人生观和价值观的培养。

例如, 在学习人教版小学语文课程中关于《一个中国孩子的呼声》 的内容时, 教师可以明确课程内容, 搜集近年来的局部战争情况资料, 并在课堂上组织学生有感情的朗读课文, 让学生理解信的主要内容, 并 深入体会作者所要表达的真挚情感, 教师可以对学生进行分组, 鼓励学 生谈论自己学习课文的感受, 认识到 “世界并不太平, 不少地区还弥漫 着战争的硝烟, 罪恶的子弹还威胁着娇嫩的 “和平之花”, 从而树立热 爱和平、维护和平的信念。

2.3 结合信息技术的特点, 营造良好的语文道德氛围

在语文课程中适应立德树人的教学要求, 开展对学生的德育培养, 就需要了解到环境对学生的重要影响, 在课堂教学中积极进行对语文道 德氛围的营造培养, 利用信息技术的特点, 利用多媒体刺激学生的视觉 和听觉, 形成独特的教学情境, 引导学生进行学习和体验, 让学生可以 在语文知识点的学习过程中得到情感上的熏陶, 促进学生品德的发展。

例如, 在指导学习学习人教版小学语文课程中关于《圆明园的毁灭》 的内容时, 教师可以在课前寻找一些关于圆明园的信息资料, 通过多媒 体技术进行对圆明园当时盛况的再现, 从而让学生深刻的体会到昔日皇 家园林的辉煌, 再通过对圆明园的毁灭的视频片段的观看, 可以让学生 更深入的了解到圆明园是如何变成一片废墟的, 形成独特的情境, 激发 学生内心的情感, 从而让学生认识到自身的使命感和责任感, 从而培养 学生热爱祖国、复兴祖国的精神。

\section{3 结论}

综上所述, 立德树人背景下小学语文课程中进行德育渗透, 需要教 师加强对教材内容的有效挖掘, 从学生的个性特点出发, 创新语文德育 教学的新模式, 创造良好的道德情感氛围, 促进学生道德品格的培养。

\section{[参考文献]}

[1]刘红华.小学语文教育中传统文化方向的探析[J].科学大众(科学 教育),2020(02):81+67.

[2]李长东.浅析传统文化教育在小学语文阅读教学中的融入[J].才 智,2020(05):197.

[3]刘惠琼.关于小学语文优秀传统文化教育的探讨 [J]. 学周 刊,2019(36):47. 